Article

\title{
Incomplete Share Repurchase Programs in Vietnam: Completion Rates and Short-Term Returns
}

\author{
Kien Cao ${ }^{1}$, , Thuy Nguyen ${ }^{2}$, Hong Nguyen ${ }^{1}$ and Hien Bui ${ }^{1, *}$ \\ 1 Faculty of Business Administration, Foreign Trade University, Hanoi 10000, Vietnam; \\ caokien@ftu.edu.vn (K.C.); hongnth@ftu.edu.vn (H.N.) \\ 2 Higher Education Department, Ministry of Education and Training, Hanoi 10000, Vietnam; \\ ntthuy@moet.gov.vn \\ * Correspondence: hienbt@ftu.edu.vn; Tel.: +84-904668198
}

Received: 5 August 2020; Accepted: 11 September 2020; Published: 16 September 2020

\begin{abstract}
Stock repurchases have become a preferred method of distributing cash to stockholders. However, given the high level of information asymmetry and weak corporate governance as well as poor investor protection in Vietnam, many Vietnamese firms use stock repurchases as a tool to manipulate stock prices in the market. Using event study methodology and Tobit regression models, this study examines the stock price behaviors surrounding the event dates and the impact of earnings management activities prior to the stock repurchases on the completion of repurchase announcements in Vietnam. The results show that earnings management practices prior to stock repurchase programs, the percentage of intended buyback shares, and CEO characteristics have a significant impact on the completion of these repurchase programs. Moreover, most of the windows surrounding the event dates do not have any significant abnormal movement of the stock prices. A plausible explanation is that, due to weak corporate governance and poor investor protection, Vietnamese firms send lots of misleading signals through various corporate activities, especially stock repurchase programs. Thus, these signals have less meaning to investors.
\end{abstract}

Keywords: stock repurchase; share buyback; completion rates; market efficiency; short-term returns; CEO characteristics

JEL Classification: G14; G32; G35

\section{Introduction}

Stock repurchases have become a preferred method of distributing cash to stockholders (Grullon and Michaely 2002). According to data compiled by analysts at S\&P Dow Jones Indices, S\&P 500 companies spent a record US\$806 billion buying back shares in 2018 . Following this trend, many Vietnamese firms are now repurchasing their own stocks. Table 1 provides a brief summary of the stock repurchase activity in the two major stock exchanges in Vietnam, which are the Ho Chi Minh City Stock Exchange (HoSE) and the Hanoi Stock Exchange (HNX) ${ }^{1}$. Regarding the number of stock repurchase programs, Panel A shows information on 518 stock repurchase programs in Vietnam during the period 2011-2017. On average, $48 \%$ of announced stock repurchase programs never completed. The percentages of incomplete stock repurchase programs were $41 \%$ and $63 \%$ on the HoSE and HNX, respectively. Regarding the number of repurchase shares, Panel B shows that, for 518 stock repurchase

1 The total number of stock repurchase programs in Table 1 is different than the total number of observations in our sample because that is the total number of repurchase programs before the screening process. 
programs, the number of intended repurchases was 1044.9 million shares on the HoSE and HNX. The percentages of shares repurchased were $78 \%$ and $39 \%$ on the HoSE and HNX, respectively.

Table 1. Stock repurchase in Vietnam.

\begin{tabular}{|c|c|c|c|c|}
\hline \multicolumn{5}{|c|}{ Panel A } \\
\hline \multicolumn{5}{|c|}{$\begin{array}{l}\text { This panel provides information about the number of announced stock repurchase programs and the number } \\
\text { of incomplete stock repurchase programs on the Ho Chi Minh City Stock Exchange (HoSE) and Hanoi Stock } \\
\text { Exchange (HNX) from } 2011 \text { to } 2017\end{array}$} \\
\hline & \multicolumn{2}{|c|}{ Ho Chi Minh City Stock Exchange } & \multicolumn{2}{|c|}{ Hanoi Stock Exchange } \\
\hline Year & $\begin{array}{l}\text { Announced stock } \\
\text { repurchase programs }\end{array}$ & $\begin{array}{l}\text { Incomplete stock } \\
\text { repurchase } \\
\text { programs }\end{array}$ & $\begin{array}{l}\text { Announced stock } \\
\text { repurchase programs }\end{array}$ & $\begin{array}{l}\text { Incomplete stock } \\
\text { repurchase } \\
\text { programs }\end{array}$ \\
\hline 2011 & 4 & 0 & 4 & 2 \\
\hline 2012 & 100 & 63 & 78 & 58 \\
\hline 2013 & 55 & 33 & 39 & 26 \\
\hline 2014 & 26 & 13 & 10 & 8 \\
\hline 2015 & 33 & 5 & 19 & 11 \\
\hline 2016 & 65 & 15 & 12 & 4 \\
\hline 2017 & 58 & 10 & 15 & 2 \\
\hline Total & 341 & 139 & 177 & 111 \\
\hline \multicolumn{5}{|c|}{ Panel B } \\
\hline \multicolumn{5}{|c|}{$\begin{array}{l}\text { This panel provides information about the number of intended repurchase shares and the number of actual } \\
\text { shares repurchased on the Ho Chi Minh City Stock Exchange (HoSE) and Hanoi Stock Exchange (HNX) from } \\
\qquad 2010 \text { to } 2016\end{array}$} \\
\hline & \multicolumn{2}{|c|}{ Ho Chi Minh City Stock Exchange } & \multicolumn{2}{|c|}{ Hanoi Stock Exchange } \\
\hline Year & $\begin{array}{l}\text { Number of intended } \\
\text { repurchase share } \\
\text { (million shares) }\end{array}$ & $\begin{array}{l}\text { Number of shares } \\
\text { repurchased } \\
\text { (million shares) }\end{array}$ & $\begin{array}{l}\text { Number of intended } \\
\text { repurchase share } \\
\text { (million shares) }\end{array}$ & $\begin{array}{l}\text { Number of shares } \\
\text { repurchased } \\
\text { (million shares) }\end{array}$ \\
\hline 2011 & 1.3 & 1.3 & 2.2 & 0.9 \\
\hline 2012 & 154.8 & 77.7 & 47.2 & 17.1 \\
\hline 2013 & 147.4 & 125.9 & 23.5 & 6.9 \\
\hline 2014 & 67.1 & 55.7 & 61.9 & 18.5 \\
\hline 2015 & 35.3 & 24.2 & 60.8 & 26.2 \\
\hline 2016 & 191.6 & 148.6 & 30.7 & 18.5 \\
\hline 2017 & 220.9 & 206.8 & 0.2 & 0.1 \\
\hline Total & 818.4 & 640.2 & 226.5 & 88.2 \\
\hline
\end{tabular}

Given the high level of information asymmetry and weak corporate governance as well as poor investor protection in Vietnam, many Vietnamese firms use stock repurchases as a tool to manipulate stock prices in the market. As pointed out by Guay and Harford (2000) and Jagannathan et al. (2000), Vietnamese managers have considerable flexibility concerning when and how to implement the stock repurchase transactions. Moreover, the actual repurchases often deviate substantially from the announced amounts, as indicated by Stephens and Weisbach (1998). Thus, examining the factors affecting the completion rate of stock repurchases is crucial in understanding the quality of the signals that the management sends to investors through the stock repurchase announcements.

This study contributes to the literature by examining the impact of earnings management activities prior to the stock repurchases on the completion of repurchase announcements in Vietnam. We also examine the stock price behavior surrounding the stock repurchase announcements, which include both the repurchase expiration date and the repurchase result announcement date. Moreover, by splitting our sample into two groups, the complete group and the incomplete group, we can show the market reaction to the completion of repurchases. In Vietnam, there is a requirement that firms must publicly announce the intention to repurchase prior to execution. However, most firms ignore this 
requirement and the State Securities Commission does not pay enough attention to this matter. Thus, there is no record for the repurchase intention announcement date. Until 2017, Vietnamese firms had the option to announce results of repurchase programs 10 days following the repurchase expiration date. In fact, most of the firms choose to publicly announce the results of repurchase programs after the expiration date. Therefore, by examining the stock price behaviors surrounding the repurchase expiration date and the repurchase result announcement date, we also shed light on the efficiency of the Vietnam stock market.

Specifically, we examine a sample of 237 open market repurchases announced in Vietnam from 2011 to 2017. Using Tobit regression models, we find that earnings management practices prior to stock repurchase programs have a significant impact on the completion of the repurchase programs. In line with Chan et al. (2010) and Andriosopoulos et al. (2013), the percentage of intended buyback shares and CEO characteristics also have an impact on the completion of repurchases. In addition, the results suggest that cash shortage is not a primary reason for incomplete repurchase programs in Vietnam. Moreover, by applying a standard event study methodology, the results show that most of the windows surrounding the expiration and result announcement dates do not have any significant abnormal movement of the stock prices. A plausible explanation is that, due to weak corporate governance and poor investor protection, Vietnam firms send lots of misleading signals through various corporate activities, especially stock repurchase programs. Thus, these signals have less meaning to investors.

\section{Literature Review}

Stock repurchase programs are usually a positive signal for the market about the value of firms. Regarding the positive abnormal returns of stock repurchase activities, Lakonishok and Vermaelen (1990) find a trading rule that involves buying shares six days prior to the expiration of the repurchase tender offer and tendering those shares whenever the stock price trades at least $3 \%$ below the tender price. Using this trading rule, the authors report a $6.18 \%$ abnormal return, with $89.1 \%$ of the trades resulting in positive abnormal returns. Liu and Ziebart (1997) also show that the market overreacts to repurchase announcements that are deemed to be "good news" by the market. Chan et al. (2004) document that market reaction to repurchase announcements in the U.S. is positive and suggests that shareholders generally benefit from these announcements. Andriosopoulos and Lasfer (2015) also report a positive market reaction to repurchase announcements in Europe. However, the average market reaction is lower than in the U.S. and is not dependent on the level of investor protection. Hatakeda and Isagawa (2004) find that stock prices in Japan go up in response to stock repurchase announcements. Looking at a sample of firms from 31 non-US countries, Manconi et al. (2019) find that, at least on average, buyback announcements made by non-U.S. companies are followed by significant positive short-term and long-term excess returns.

Many studies examine the reasons why firms engage in stock repurchase as well as the positive economic value of this activity. There are various reasons for firms engaging in stock repurchase programs. Chan et al. (2004) show three motivations for firms to buy back stock, which are mispricing, disgorging free cash flow, and altering the capital structure. Andriosopoulos and Lasfer (2015) discuss these motivations but also consider dividend substitution, management compensation incentives, and firm reputation as motivations for stock repurchase. Other studies mention takeover deterrence and dilution minimization incentives for firms to buyback stocks, such as Bagwell (1991a, 1991b), Brav et al. (2005), Kahle (2002), and Bens et al. (2003). In terms of an emerging market, Moin et al. (2020) examine the agency cost of free cash flows in the context of share repurchase programs, particularly in Indonesia. The authors investigate the effects of various sub-optimal financial decisions, such as excess cash holdings and leverage positions, on share repurchase decisions.

On the other hand, open market and tender offer stock repurchase programs are not a firm commitment and recent studies show that stock repurchase programs are also used as a potential tool to mislead investors. Stephens and Weisbach (1998) show that only a fraction of announced open market repurchases ever take place. Stephen and Weisbach consider four completion rate metrics: (1) 
Center for Research in Security Price (CRSP) decrease in share outstanding, (2) Compustat decrease in share outstanding, (3) net dollars spent on repurchases divided by the low price, and (4) the net dollars spent on repurchases divided by the average price. Using data from 1981 to 1990, the authors report that firms, on average, acquire $74 \%$ to $82 \%$ of the shares announced as repurchase targets within three years of the repurchase announcement. Bhattacharya and Dittmar (2004) argue that managers have the ability to authorize an open market buyback program even if there is no intention to buy back stock, thus creating the potential for cheap talk. The authors show that firms announce buyback programs but do not repurchase because the managers could benefit from the false undervaluation signals. In this situation, the more managers might attract scrutiny, the greater the false undervaluation benefit for them. Fried (2005) shows evidence that managers intend to increase stock prices by announcing repurchase programs that they do not plan to implement. Babenko et al. (2012) show that managers are more likely to complete their repurchase plans if they can receive higher benefits. Moreover, Andriosopoulos et al. (2013) relate CEO traits to share buyback completion rates and find that firms with more senior CEOs who have more corporate connections and longer tenures as CEO are significantly more likely to complete the firms' share buyback programs.

There is also a line of literature that examines the use of stock repurchase programs as an earnings management mechanism. Previous literature shows that managers have motivations to manipulate the firm's earnings around specifically financial events such as initial public offerings, seasoned equity offerings, merger and acquisitions, and stock repurchases. Vafeas et al. (2003) argue that earnings management is likely to take place around corporate transactions where investors are invited to trade firm securities because of the higher cost of information asymmetry around such transactions and because in these cases the temporary misstatement of the firm's financial position is likely to lead to permanent wealth transfers from uninformed investors to informed insiders. The U.S. Securities and Exchange Commission is aware of the possibility of manipulation before stock repurchases ${ }^{2}$.

Earlier studies suggest that managers might employ stock repurchases and use discretionary accruals as substitutes or as complementary devices of earnings management. Barclay and Smith (1988) conjecture that share repurchases, unlike dividends, create incentives for managers to manipulate information flows. Chen (2007) employs both a discretionary current accrual model and non-discretionary current accrual model to estimate the level of earnings management. The results show that firms with a higher level of discretionary current accruals or higher degree of earnings management would be more likely to leave the repurchase programs incomplete. Cooper et al. (2008) show that firms engage in income-decreasing real earnings management before open market stock repurchases to reduce the cost of stock buybacks. Brockman et al. (2008) show that managers increase the frequency and magnitude of bad news announcements during the one-month period prior to repurchasing shares. Moreover, managers also increase the frequency and magnitude of good news announcements during the one-month period following the repurchases. Bens et al. (2003) find that managers increase stock repurchases when earnings do not meet the past growth rates and, thus, managers' repurchase decisions are affected by their incentives to manage EPS. Francis et al. (2015) also report evidence of downward real-activity earnings management around firm repurchase announcements. Gong et al. (2008) find that companies manipulate their required disclosures preceding stock repurchases by managing their reported earnings downward through income-decreasing discretionary accruals. Chen and Liu (2020) show that earnings management is negatively related to the probability and frequency of share repurchase announcements. Their findings support the prediction that the magnitude of earnings management can serve as a reliable indicator of managers' mindsets regarding the valuation of firms. This study differs from previous studies by investigating the impact of earnings management on the completion rate of share repurchase programs in an emerging market, which is Vietnam.

2 In a comment letter issued in July of 2015 by the U.S. Securities and Exchange Commission chairperson, Mary Jo White. 


\section{Data and Methodology}

\subsection{Data}

Our initial sample consists of 518 open market stock repurchase announcements from 2011 to 2017 provided by FiinGroup ${ }^{3}$. Only observations that satisfy certain screening criteria were included in the investigation. First, we eliminated all observations in which the intended buyback number of shares is less than $0.5 \%$ of the total number of shares outstanding. Second, we removed all utility and financial firms from our sample. Until 2017, Vietnamese firms had the option to announce the results of the repurchase programs 10 days after the repurchase expiration date. After the screening process, there were only 10 buyback firms that announce results of repurchase programs before or on the expiration date. Thus, we also eliminated these observations. There are 237 observations that satisfy our criteria.

\subsection{Methodology}

In order to estimate earnings management, we followed Teoh et al. (1998) in calculating discretionary and nondiscretionary accruals. The current accrual can be proxied as the difference between the change in non-cash current assets and the change in current liabilities:

$$
\mathrm{CA}_{i, t}=\Delta A R_{j, t}+\Delta I_{j, t}+\Delta O C A_{j, t}-\Delta C L_{j, t} .
$$

where (for firm $j$ ):

$\mathrm{CA}_{j, t}$ is the current accruals from year $t-1$;

$\Delta A R_{j, t}$ is the change in accounts receivable from year $t-1$;

$\Delta I_{j, t}$ is the change in inventory from year $t-1$;

$\triangle O C A_{j, t}$ is the change in other current assets from year $t-1$;

$\Delta C L_{j, t}$ is the change in accounts payable from year $t-1$.

Following Jones (1991), we run the regression model:

$$
\frac{\mathrm{CA}_{j, t}}{T A_{j, t-1}}=\alpha_{0} \cdot \frac{1}{T A_{j, t-1}}+\alpha_{1} \frac{\Delta \text { Sales }_{j, t}}{T A_{j, t-1}}+\varepsilon_{j, t}
$$

where (for firm $j$ ):

$\Delta$ Sales $_{j, t}$ is the change in sales from year $t-1$;

$T A_{j, t-1}$ is the total assets in year $t-1$;

$\alpha_{0}$ and $\alpha_{1}$ are coefficient estimates by the Ordinary Least Square regression model;

$\varepsilon_{j, t}$ is the error term in year $t$.

The nondiscretionary current accruals (NDCAs) are considered as the independence of managerial control and can be calculated as:

$$
N D C A_{j, t}=\hat{\alpha_{0}} \cdot \frac{1}{T A_{j, t-1}}+\hat{\alpha_{1}} \cdot \frac{\Delta \text { Sales }_{j, t}-\Delta A R_{j, t}}{T A_{j, t-1}}
$$

3 FiinGroup is the leading financial and business information corporation in Vietnam. The company provides the most comprehensive ready-to-use financial information platform, business information portal, standard and customizable research reports, and value added services in Vietnam. 
The residual, which represents the portion of current accruals that can be manipulated by management, is the discretionary current accruals and can be calculated as:

$$
D C A_{j, t}=\frac{\mathrm{CA}_{j, t}}{T A_{j, t-1}}-N D C A_{j, t}
$$

In addition, we also used the discretionary total accruals as another variable representing the earnings management. To calculate the discretionary total accruals (DA), we employed a similar method as for current accruals.

$\mathrm{AC}=$ Net Income - Cash Flows from Operations

$$
\begin{gathered}
\frac{\mathrm{AC}}{j, t}=\beta_{0} \cdot \frac{1}{T A_{j, t-1}}+\beta_{1} \frac{\Delta \text { Sales }_{j, t}}{T A_{j, t-1}}+\beta_{2} \cdot \frac{P P E_{j, t}}{T A_{j, t-1}}+\varepsilon_{j, t} \\
N D A_{j, t}=\hat{\beta_{0}} \cdot \frac{1}{T A_{j, t-1}}+\hat{\beta_{1}} \cdot \frac{\Delta \text { Sales }_{j, t}-\Delta A R_{j, t}}{T A_{j, t-1}}+\hat{\beta_{2}} \cdot \frac{P P E_{j, t}}{T A_{j, t-1}} \\
D A_{j, t}=\frac{\mathrm{AC}}{T A_{j, t}-1}-N D A_{j, t}
\end{gathered}
$$

where (for firm $j$ ):

$\mathrm{AC}_{j, t}$ is the total accruals in year $t$;

$P P E_{j, t}$ is the gross property, plants, and equipment in year $t ;$

$N D A_{j, t}$ is the non-discretionary total accruals in year $t$;

$D A_{j, t}$ is the discretionary total accruals in year $t$;

$\beta_{0}, \beta_{1}$ and $\beta_{2}$ are coefficient estimates by the OLS regression model;

$\varepsilon_{j, t}$ is the error term in year $t$.

In order to distinguish between complete and incomplete stock repurchase programs, we applied the Probit regression model:

$$
P\left(Y_{i}=1\right)=1-F\left(\frac{-\alpha-\beta X_{i}}{\sigma}\right), P\left(Y_{i}=0\right)=F\left(\frac{-\alpha-\beta X_{i}}{\sigma}\right)
$$

where:

$Y_{i}=1$ if the repurchase program is complete, $Y_{i}=0$ if the repurchase program is incomplete;

$X_{i}$ is a vector of independent variables.

Moreover, we applied the Tobit regression model to examine the factors affecting the completion rate of stock repurchase programs:

$$
\text { Buyback completion }_{i}=\beta X_{i}+u_{i}
$$

where:

Buyback completion ${ }_{i}$ is the ratio of shares bought back over the announced number of shares; $X_{i}$ is a vector of independent variables.

Following earlier literature, we used various variables to explain the completion of stock repurchase programs. Despite the fact that the private sector in Vietnam has been growing at a rapid rate, the state enterprises still have a leading role in the economy. Thus, we also investigated the impact of state ownership on the completion rate. Appendix A provides a summary of the variables, along with their definitions. We also employed a standard event study method to examine the stock price behavior surrounding the stock repurchase announcements. We used the market adjusted model for estimation, with an estimation period from $t=-300$ to $t=-46$ days relative to the event day $t=0$. Cumulative abnormal returns (CARs) for different windows were calculated. 


\section{Univariate Results}

Table 2 provides the completion rates of the sample and the ranked percentiles based on the completion rates. Only $24.47 \%$ of the sample announcements are complete and $9.7 \%$ of the sample announcements did not buy back any shares. More than $50 \%$ of the sample announcements repurchased less than $60 \%$ of the announced shares. We also found that the average completion rate for all samples is $52.64 \%$. For the incomplete repurchase programs, the average completion rate is $37.3 \%$.

Table 2. The ranked completion percentiles of the sample.

\begin{tabular}{ccc}
\hline Percentile & Number of Announcements & Percent of the Sample (\%) \\
\hline $0 \%$ & 23 & 9.70 \\
$0.1 \%-20 \%$ & 46 & 19.41 \\
$21 \%-40 \%$ & 32 & 13.50 \\
$41 \%-60 \%$ & 34 & 14.35 \\
$61 \%-80 \%$ & 20 & 8.44 \\
$81 \%-99 \%$ & 24 & 10.13 \\
$100 \%$ & 58 & 24.47 \\
Total & 237 & 100 \\
\hline
\end{tabular}

This table reports the number and percentage of announcements that completed the repurchase programs and those that left repurchase programs incomplete.

Table 3 shows the distribution of the open market share repurchase announcements by calendar year. The majority of the announcements are in the period 2011-2013. More than $75 \%$ of the sample announcements and $60 \%$ of the incomplete repurchase programs are in this period. Moreover, there is a decreasing tendency in the number of stock repurchase programs from 2011 to 2017.

Table 3. Yearly distribution of repurchase programs.

\begin{tabular}{ccccccc}
\hline Year & \multicolumn{3}{c}{ Total Sample } & \multicolumn{3}{c}{ Incomplete Repurchase Programs } \\
\cline { 2 - 6 } & $\begin{array}{c}\text { No. of } \\
\text { Observations }\end{array}$ & $\begin{array}{c}\text { \% of Total } \\
\text { Sample }\end{array}$ & $\begin{array}{c}\text { Mean } \\
\text { Completion } \\
\text { Rate }\end{array}$ & $\begin{array}{c}\text { No. of } \\
\text { Observations }\end{array}$ & $\begin{array}{c}\text { \% of Total } \\
\text { Sample }\end{array}$ & $\begin{array}{c}\text { Mean } \\
\text { Completion } \\
\text { Rate }\end{array}$ \\
\hline 2011 & 5 & 2.1 & 72.79 & 2 & 0.84 & 31.96 \\
2012 & 115 & 48.5 & 48.12 & 91 & 38.40 & 34.43 \\
2013 & 61 & 25.7 & 56.17 & 46 & 19.41 & 41.88 \\
2014 & 18 & 7.6 & 59.61 & 13 & 5.49 & 44.08 \\
2015 & 11 & 4.6 & 58.57 & 8 & 3.38 & 43.03 \\
2016 & 19 & 8.0 & 44.13 & 14 & 5.91 & 24.18 \\
2017 & 8 & 3.4 & 74.64 & 5 & 2.11 & 59.42 \\
Total & 237 & 100 & 52.64 & 179 & 75.53 & 37.30 \\
\hline
\end{tabular}

This table reports the annual distribution of stock repurchase announcements and the completion rates of the respective announcements.

Table 4 reports the descriptive statistics for the variables that potentially influence the completion rates of stock repurchase programs. Both the NDCAs and DCAs have a mean of 0.01. However, NDAs and DAs have means of 0.24 and -0.17 , respectively. The mean repurchase size is $5 \%$ of the total number of outstanding shares. BTM ratio has a mean of 2.22. The mean of the ratio of total debts to total equities is 1.19 , indicating that sampled firms do not have an excessively high level of debts. In general, repurchase firms have a healthy operating cash flow with the 0.04 mean of OCF. The majority of the samples have a low state control mechanism with the mean of STATE being 18 . Table 4 also shows that the mean CEO age is 47 years, with a minimum of 28 years and a maximum of 68 years. On average, the CEO tenure is approximately 4 years, with a minimum of one year and a maximum of 25 years. Only $21 \%$ of the CEOs have a master's degree or above and $93 \%$ of the CEOs are male. 
Table 4. Descriptive statistics of the sample.

\begin{tabular}{cccccc}
\hline Variable & No. of Observations & Mean & Median & Min & Max \\
\hline NDCA & 237 & 0.01 & 0 & -0.07 & 0.21 \\
DCA & 237 & 0.01 & 0.01 & -1.46 & 0.92 \\
NDA & 237 & 0.24 & 0.20 & -0.02 & 0.89 \\
DA & 237 & -0.17 & -0.15 & -0.88 & 0.71 \\
INTEND & 237 & 5 & 4 & 1 & 25 \\
BTM & 237 & 2.22 & 2.3 & 0.13 & 8.25 \\
TA & 237 & 629 & 537 & 15 & 71,850 \\
LEV & 237 & 1.19 & 0.91 & 0.04 & 9.11 \\
OCF & 237 & 0.04 & 0.03 & -0.45 & 0.41 \\
CASH & 237 & 0.20 & 0.14 & 0 & 0.75 \\
STATE & 237 & 18 & 8 & 0 & 97 \\
CEOEDU & 236 & 0.21 & 0 & 0 & 1 \\
CEOTENURE & 236 & 4 & 5 & 1 & 25 \\
CEOAGE & 237 & 49 & 50 & 28 & 68 \\
CEOGEN & 237 & 0.93 & 1 & 0 & 1 \\
IND1 & 237 & 0.16 & 0 & 0 & 1 \\
IND2 & 237 & 0.02 & 0 & 0 & 1 \\
\hline
\end{tabular}

This table presents the descriptive statistics for the variables used in this study. DCA is the pre-stock repurchase discretionary current accruals. NDCA is the pre-stock repurchase non-discretionary current accruals. NDA is the pre-stock repurchase non-discretionary total accruals. DA is the pre-stock repurchase discretionary total accruals. INTEND is the ratio of the intended number of buyback shares to the total number of outstanding shares. BTM is the natural $\log$ of 1 plus the ratio of the book value to the market value at the end of the previous fiscal year. TA is the total assets in billion Vietnamese Dongs at the end of the previous fiscal year. LEV is the ratio of total debts to total equities at the end of the previous fiscal year. OCF is the ratio of operating cash flows to total assets at the end of the previous fiscal year. CASH is the ratio of cash plus short-term investment to total assets at the end of the previous fiscal year. STATE is the percentage of state ownership. CEOEDU equals 1 if the CEO has a master's degree or above, 0 otherwise. CEOTENURE is the number of years as CEO. CEOAGE is the age of the CEO in the announcement year. CEOGEN equals 1 if the CEO is male, 0 otherwise. IND1 equals 1 if the buyback firm is a real estate company, 0 otherwise. IND2 equals 1 if the buyback firm is a high tech company, 0 otherwise.

\section{Multivariate Results}

In this section, we test which factors have a significant impact on the completion of the announced open market buyback programs. Table 5 reports the results of the Probit regression models, explaining the factors influencing the completion of repurchase programs. The results show that pre-stock repurchase discretionary current accruals have a significant and positive impact on the completion probability of stock repurchase programs, indicating that firms with higher discretionary current accruals are more likely to complete the repurchase programs. The pre-stock repurchase discretionary total accruals also have a significant impact on the completion probability of stock repurchase programs. However, the discretionary total accruals negatively impact the completion probability. This result suggests that firms with lower discretionary total accruals are more likely to complete the repurchase programs. On the other hand, the pre-stock repurchase non-discretionary current accruals and pre-stock repurchase discretionary total accruals have an insignificant impact on the completion probability of stock repurchase programs. The results support findings from Cooper et al. (2008), who showed that firms engage in real earnings management before open market stock repurchases to reduce the cost of stock buybacks. These findings also provide linkage between the earnings management practice and the probability of completing repurchase programs in Vietnam. 
Table 5. Probit regression explaining the factors influencing the completion of repurchase programs.

\begin{tabular}{|c|c|c|c|c|c|c|}
\hline \multirow{2}{*}{ Variable } & \multicolumn{2}{|c|}{ Model 1} & \multicolumn{2}{|c|}{ Model 2} & \multicolumn{2}{|c|}{ Model 3} \\
\hline & Coef. & $z$-Score & Coef. & $z$-Score & Coef. & $z$-Score \\
\hline Constant & -2.416 & -1.26 & -1.226 & -0.7 & -5.367 & -1.7 \\
\hline DCA & $1.244^{* *}$ & 2.03 & & & & \\
\hline NDCA & -3.98 & -0.86 & & & & \\
\hline NDA & & & -29.83 * & -1.89 & & \\
\hline DA & & & -0.787 & -0.81 & & \\
\hline CEOEDU & & & & & $0.423 * *$ & 1.85 \\
\hline CEOTENURE & & & & & -0.053 & -0.45 \\
\hline CEOAGE & & & & & $1.18^{*}$ & 1.72 \\
\hline CEOGEN & & & & & -0.229 & -0.6 \\
\hline INTEND & $-0.041 *$ & -1.64 & $-0.05^{* *}$ & -2.00 & $-0.041 *$ & -1.62 \\
\hline BTM & -0.099 & -0.67 & -0.144 & -0.9 & -0.113 & -0.71 \\
\hline $\mathrm{TA}$ & 0.085 & 1.23 & 0.054 & 0.87 & 0.035 & 0.56 \\
\hline LEV & -0.056 & -0.61 & -0.079 & -0.84 & -0.051 & -0.56 \\
\hline OCF & $1.415^{*}$ & 1.8 & -0.257 & -0.2 & 0.686 & 0.95 \\
\hline CASH & $-1.333^{* *}$ & -2.04 & -1.041 & -1.52 & $-1.289 * *$ & -1.92 \\
\hline STATE & -0.002 & -0.48 & -0.002 & -0.46 & -0.003 & -0.55 \\
\hline IND1 & -0.345 & -1.22 & -0.468 * & -1.62 & -0.37 & -1.34 \\
\hline IND2 & 0.271 & 0.35 & -0.019 & -0.02 & 0.066 & 0.09 \\
\hline No. of Obs. & 237 & 237 & 237 & 237 & 236 & 236 \\
\hline Pseudo $\mathrm{R}^{2}$ & \multicolumn{2}{|c|}{$11.23 \%$} & \multicolumn{2}{|c|}{$12.16 \%$} & \multicolumn{2}{|c|}{$11.69 \%$} \\
\hline
\end{tabular}

This table presents the results of Probit regression models explaining the factors influencing the completion of repurchase programs for a sample of 237 repurchase announcements from 2011 to 2017. The dependent variable is the Complete dummy, which equals 1 if the firm completes the program, 0 otherwise. DCA is the pre-stock repurchase discretionary current accruals. NDCA is the pre-stock repurchase non-discretionary current accruals. NDA is the pre-stock repurchase non-discretionary total accruals. DA is the pre-stock repurchase discretionary total accruals. INTEND is the ratio of the intended number of buyback shares to the total number of outstanding shares. BTM is the natural log of 1 plus the ratio of the book value to the market value at the end of the previous fiscal year. TA is the natural logarithm of the total assets in billion Vietnamese Dongs at the end of the previous fiscal year. LEV is the ratio of total debts to total equities at the end of the previous fiscal year. OCF is the ratio of operating cash flows to total assets at the end of the previous fiscal year. CASH is the ratio of cash plus short-term investment to total assets at the end of the previous fiscal year. STATE is the percentage of state ownership. CEOEDU equals 1 if the CEO has a master's degree or above, 0 otherwise. CEOTENURE is the natural logarithm of the number of years as CEO. CEOAGE is the natural logarithm of the age of the CEO in the announcement year. CEOGEN equals 1 if the $\mathrm{CEO}$ is male, 0 otherwise. IND1 equals 1 if the buyback firm is a real estate company, 0 otherwise. IND2 equals 1 if the buyback firm is a high tech company, 0 otherwise. * and ** indicate statistical significance at the $10 \%$ and $5 \%$ levels, respectively.

The results suggest that $\mathrm{CEO}$ characteristics also influence the completion probability of stock repurchase programs. CEO education and CEO age both have a positive and significant impact on the completion probability. Chevalier and Ellison (1999) and Andriosopoulos et al. (2013) argue that older and more highly educated CEOs have a better understanding of the firm's fundamentals and their shareholders' requirements, carrying out their promise to buyback shares and completing the respective buyback programs. Thus, the above results are in line with the studies by Chevalier and Ellison (1999) and Andriosopoulos et al. (2013). The ratio of the intended number of buyback shares to the total number of outstanding shares has a significant and negative impact on the completion probability of stock repurchase programs. This result indicates that the probability of repurchase completion is significantly lower if managers announce to buyback a greater percentage of the outstanding shares, supporting evidence from Chan et al. (2010). Interestingly, CASH is negative and significant related to the probability of completing buyback program. The result suggests that a cash shortage is not a primary reason for incomplete repurchase programs.

Table 6 reports the results of the Tobit regression models explaining the factors influencing the completion rate of repurchase programs. The results in Table 6 strengthen the findings in Table 5 . The pre-stock repurchase discretionary current accruals and CEO education have significant and positive impacts on the completion rate of repurchase programs. On the other hand, the pre-stock 
repurchase discretionary total accruals, the ratio of the intended number of buyback shares to the total number of outstanding shares and the ratio of cash plus short-term investment to total assets have a significant and negative impact on the completion rate of repurchase programs. Moreover, the results also provide limited evidence that firms with female CEO have a higher completion rate compared to that of firms with a male CEO. These results conflict with the findings from Barber and Odean (2001), Andriosopoulos et al. (2013), who show that firms with male CEOs are more likely to complete stock repurchases.

Table 6. Tobit regression explaining the factors influencing the completion rate of repurchase programs.

\begin{tabular}{|c|c|c|c|c|c|c|}
\hline \multirow{2}{*}{ Variable } & \multicolumn{2}{|c|}{ Model 1} & \multicolumn{2}{|c|}{ Model 2} & \multicolumn{2}{|c|}{ Model 3} \\
\hline & Coef. & $z$-Score & Coef. & $z$-Score & Coef. & $z$-Score \\
\hline Constant & 0.751 & 1.12 & 0.957 & 1.57 & 0.819 & 0.81 \\
\hline DCA & 0.261 * & 1.71 & & & & \\
\hline NDCA & -0.581 & -0.41 & & & & \\
\hline NDA & & & $-56.389 *$ & -1.67 & & \\
\hline DA & & & -0.531 & -1.41 & & \\
\hline CEOEDU & & & & & $0.166^{* *}$ & 2.01 \\
\hline CEOTENURE & & & & & 0.013 & 0.32 \\
\hline CEOAGE & & & & & 0.104 & 0.48 \\
\hline CEOGEN & & & & & $-0.247^{*}$ & -1.87 \\
\hline INTEND & $-0.016^{*}$ & -1.78 & $-0.019^{* *}$ & -2.09 & $-0.016^{*}$ & -1.72 \\
\hline BTM & -0.017 & -0.36 & -0.033 & -0.7 & -0.018 & -0.39 \\
\hline TA & 0.001 & 0.02 & -0.003 & -0.11 & -0.009 & -0.42 \\
\hline LEV & -0.007 & -0.23 & -0.022 & -0.71 & -0.008 & -0.25 \\
\hline OCF & 0.309 & 1.22 & -0.431 & -1.06 & 0.196 & 0.85 \\
\hline $\mathrm{CASH}$ & -0.373 * & -1.8 & -0.218 & -0.99 & $-0.424^{* *}$ & -2.02 \\
\hline STATE & -0.001 & -0.67 & -0.001 & -0.58 & -0.008 & -0.48 \\
\hline IND1 & 0.073 & 0.79 & 0.012 & 0.14 & 0.015 & 0.16 \\
\hline IND2 & 0.028 & 0.12 & -0.032 & -0.14 & -0.054 & -0.25 \\
\hline No. of Obs. & 237 & 237 & 237 & 237 & 236 & 236 \\
\hline $\begin{array}{c}\text { McFadden's } \\
\mathrm{R}^{2}\end{array}$ & \multicolumn{2}{|c|}{$16.23 \%$} & \multicolumn{2}{|c|}{$15.86 \%$} & \multicolumn{2}{|c|}{$15.19 \%$} \\
\hline
\end{tabular}

This table presents the results of the Tobit regression models explaining the factors influencing the completion rate of repurchase programs for a sample of 237 repurchase announcements from 2011 to 2017. The dependent variable is the Completion Rate, which is the percentage of the repurchased shares relative to the targeted amount at the time of the announcement. DCA is the pre-stock repurchase discretionary current accruals. NDCA is the pre-stock repurchase non-discretionary current accruals. NDA is the pre-stock repurchase non-discretionary total accruals. DA is the pre-stock repurchase discretionary total accruals. INTEND is the ratio of the intended number of buyback shares to the total number of outstanding shares. BTM is the natural log of 1 plus the ratio of the book value to the market value at the end of the previous fiscal year. TA is the natural logarithm of the total assets in billion Vietnamese Dongs at the end of the previous fiscal year. LEV is the ratio of total debts to total equities at the end of the previous fiscal year. OCF is the ratio of operating cash flows to total assets at the end of the previous fiscal year. CASH is the ratio of cash plus short-term investment to total assets at the end of the previous fiscal year. STATE is the percentage of state ownership. CEOEDU equals 1 if the CEO has a master's degree or above, 0 otherwise. CEOTENURE is the natural logarithm of the number of years as CEO. CEOAGE is the natural logarithm of the age of the CEO in the announcement year. CEOGEN equals 1 if the CEO is male, 0 otherwise. IND1 equals 1 if the buyback firm is a real estate company, 0 otherwise. IND2 equals 1 if the buyback firm is a high-tech company, 0 otherwise. ${ }^{*}$ and ${ }^{* *}$ indicate statistical significance at the $10 \%$ and $5 \%$ levels, respectively.

Table 7 shows the cumulative abnormal returns for the final sample of stock repurchase programs in Vietnam from 2011 to 2017. The abnormal returns surrounding the repurchase expiration date and the repurchase result announcement date were reported, using a market-adjusted model. We examined the cumulative abnormal returns during the $(-10,10),(-5,5),(-3,3)$, and $(-1,1)$ windows surrounding the repurchase expiration date and the repurchase result announcement date. Previous studies show a positive stock price reaction to the announcement of the intention to repurchase shares (Andriosopoulos and Lasfer 2015; Chan et al. 2004; Ginglinger and L’Her 2006; Ikenberry et al. 1995; 
and Vermaelen 1981). Our results differ from the previous literature by examining the stock price reaction to the announcement of stock repurchase program results.

Table 7. Cumulative abnormal returns for different windows surrounding expiration and announcement dates.

\begin{tabular}{cccc}
\hline \multirow{2}{*}{ Window } & Whole Sample & Incomplete Repurchases & Complete Repurchases \\
\cline { 2 - 4 } & CAR (\%) & CAR (\%) & CAR (\%) \\
\hline END21 & -0.789 & -0.745 & -0.297 \\
END11 & 0.33 & 0.102 & 0.455 \\
END7 & 0.928 & 0.993 & 0.093 \\
END3 & -0.02 & 0.165 & -0.396 \\
ANN21 & -0.663 & -0.625 & -0.244 \\
ANN11 & -1.6 & -1.504 & -0.646 \\
ANN7 & $-2.622 *$ & $-2.693 *$ & -0.722 \\
ANN3 & -1.118 & -1.377 & 0.302 \\
\hline
\end{tabular}

This table provides the cumulative abnormal returns for the sample of the stock repurchase programs in Vietnam from 2011 to 2017. The cumulative abnormal returns during $(-10,10),(-5,5),(-3,3)$, and $(-1,1)$ windows surrounding expiration and announcement dates are reported, using a market-adjusted model. For the expiration dates (END), day 0 is the last day of the buyback period. For announcement dates (ANN), day 0 is the date of the original announcement reported by StoxPlus Corporation. Parameters from the market adjusted model are estimated using OLS regression over the pre-event period, $t=-300$ to $-46 .{ }^{*}$ indicates statistical significance at the $10 \%$ level.

The results suggest that most of the windows surrounding the repurchase expiration date and the repurchase result announcement date do not have any significant abnormal movement of the stock prices. A plausible explanation is that investors do not pay much attention to the news about repurchase programs of Vietnamese firms. Due to weak corporate governance and poor investor protection, Vietnam's firms send lots of misleading signals through various corporate activities, especially stock repurchase programs. Appendix B presents information regarding the Corporate Governance Index and Investor Protection Index in various countries, indicating that Vietnam has weaker corporate governance and poorer investor protection compared to that of developed countries and most ASEAN countries. In Vietnam, the repurchase firms do not even follow the requirements to announce the intention to repurchase shares publicly. Thus, the signals from firms have less meaning to investors.

On the other hand, only the $(-3,3)$ window surrounding the announcement date has a significantly negative movement of the stock prices, especially for incomplete repurchases.

The stock market punishes firms that did not complete their repurchase programs when the news is released. Table 8 reports the results of OLS regression models explaining cumulative abnormal returns during the $(-3,3)$ window surrounding announcement dates. Similar to the results in Tables 5 and 6, earnings management activities prior to the repurchase announcements significantly influence the abnormal returns. Specifically, the pre-stock repurchase discretionary current accruals, the pre-stock repurchase non-discretionary total accruals, and the pre-stock repurchase discretionary total accruals have a positive and significant impact on the cumulative abnormal returns surrounding announcement dates. These results suggest that firms engaging in earnings management practices prior to repurchases realize significantly higher cumulative abnormal returns compared to other firms. There is also evidence indicating that firms with higher state ownership suffer more from incomplete repurchase programs. 
Table 8. OLS regression explaining the cumulative abnormal returns surrounding announcement dates.

\begin{tabular}{|c|c|c|c|c|c|c|}
\hline \multirow{2}{*}{ Variable } & \multicolumn{2}{|c|}{ Model 1} & \multicolumn{2}{|c|}{ Model 2} & \multicolumn{2}{|c|}{ Model 3} \\
\hline & Coef. & $t$-Statistic & Coef. & $t$-Statistic & Coef. & $t$-Statistic \\
\hline Constant & -5.074 & -0.62 & & & 0.708 & 0.052 \\
\hline DCA & $6.194^{* * *}$ & 2.68 & & & & \\
\hline NDCA & -12.448 & -0.92 & & & & \\
\hline NDA & & & $9.32^{* * *}$ & 2.70 & & \\
\hline DA & & & $5.52 * *$ & 2.27 & & \\
\hline CEOEDU & & & & & -1.403 & -1.30 \\
\hline CEOTENURE & & & & & 0.203 & 0.37 \\
\hline CEOAGE & & & & & -2.483 & -0.857 \\
\hline CEOGEN & & & & & 1.585 & 0.87 \\
\hline INTEND & -0.84 & -0.70 & -0.107 & -0.88 & -0.086 & -0.70 \\
\hline BTM & 0.571 & 0.88 & 0.455 & 0.698 & 0.413 & 0.624 \\
\hline TA & 0.103 & 0.34 & 0.125 & 0.41 & 0.245 & 0.79 \\
\hline LEV & 2.815 & 1.20 & 0.63 & 0.28 & 0.135 & 0.058 \\
\hline OCF & $7.028^{* *}$ & 2.10 & 1.882 & 0.617 & 2.757 & 0.88 \\
\hline CASH & 0.314 & 0.112 & -0.837 & -0.30 & -1.347 & -0.46 \\
\hline STATE & $-0.051^{* *}$ & -2.51 & -0.032 * & -1.67 & -0.034 * & -1.66 \\
\hline IND1 & 1.60 & 0.791 & 0.289 & 0.15 & -0.07 & -0.034 \\
\hline IND2 & 1.252 & 0.99 & 2.387 * & 1.89 & $2.149 *$ & 1.69 \\
\hline No. of Obs. & 237 & 237 & 237 & 237 & 236 & 236 \\
\hline Pseudo $\mathrm{R}^{2}$ & \multicolumn{2}{|c|}{$5.87 \%$} & \multicolumn{2}{|c|}{$5.41 \%$} & \multicolumn{2}{|c|}{$5.01 \%$} \\
\hline
\end{tabular}

This table presents the results of OLS regression models explaining cumulative abnormal returns during the $(-3,3)$ window surrounding announcement dates for a sample of 237 repurchase announcements from 2011 to 2017. The dependent variable is the cumulative abnormal returns during the $(-3,3)$ window surrounding announcement dates. DCA is the pre-stock repurchase discretionary current accruals. NDCA is the pre-stock repurchase non-discretionary current accruals. NDA is the pre-stock repurchase non-discretionary total accruals. DA is the pre-stock repurchase discretionary total accruals. INTEND is the ratio of the intended number of buyback shares to the total number of outstanding shares. BTM is the natural $\log$ of 1 plus the ratio of the book value to the market value at the end of the previous fiscal year. TA is the natural logarithm of the total assets in billion Vietnamese Dongs at the end of the previous fiscal year. LEV is the ratio of total debts to total equities at the end of the previous fiscal year. OCF is the ratio of operating cash flows to total assets at the end of the previous fiscal year. CASH is the ratio of cash plus short-term investment to total assets at the end of the previous fiscal year. STATE is the percentage of state ownership. CEOEDU equals 1 if the CEO has a master's degree or above, 0 otherwise. CEOTENURE is the natural logarithm of the number of years as CEO. CEOAGE is the natural logarithm of the age of the CEO in the announcement year. CEOGEN equals 1 if the CEO is male, 0 otherwise. IND1 equals 1 if the buyback firm is a real estate company, 0 otherwise. IND2 equals 1 if the buyback firm is a high-tech company, 0 otherwise. * ** and ${ }^{* * *}$ indicate statistical significance at the $10 \%, 5 \%$, and $1 \%$ levels, respectively.

\section{Conclusions}

Using a sample of open market repurchases announced from 2011 to 2017, we examined the factors influencing the completion of stock repurchase programs in Vietnam. We found that the discretionary current accruals which are the portion of current accruals that can be manipulated by management have a significantly positive impact on the completion of repurchase programs. On the other hand, the non discretionary total accruals which are the portion of total accruals that cannot be manipulated by management have a significantly negative impact on the completion of repurchase programs. These results suggest a positive relationship between earnings management practices and the completion of stock repurchases in Vietnam. This result might affect the decision-making process of investors who follow the positive signals about the firm's prosperity by the repurchase announcements. When firms announce their stock repurchase intention, investors must pay attention to the firms' earnings management practices prior to the announcements before deciding their actions.

We also show that CEO traits affect the probability that firms will complete repurchase programs. Specifically, CEO education and CEO age have a positive and significant impact on the completion probability. Older and highly educated CEOs have a better understanding of the firm's fundamentals and their shareholders' requirements, carrying out their promise to buyback shares and thus completing the respective buyback program. 
Moreover, we apply a standard event study method to investigate the stock price behaviors surrounding stock repurchase announcements in Vietnam. We report that most of the windows surrounding the expiration and announcement dates do not have any significant abnormal movement of the stock prices. A plausible explanation for this result is the weak rule of law and inefficient law enforcement. In the context of Vietnam, firms send lots of misleading signals through various corporate activities, especially stock repurchase programs. Thus, these signals have less meaning to investors. However, despite the fact that most firms announce repurchase programs after the expiration date, the stock market punishes firms that did not complete the repurchase programs when the news is released.

Stock repurchases can be examined from different angles. Due to the data limitations, this study aims to investigate the impact of earnings management activities on the completion of repurchase programs. Moreover, it is limited to repurchase announcements of listed companies through open market operations only. Future studies might investigate the results of repurchase programs around specific firm-related events such as mergers and acquisitions, equity offerings, stock split, stock delisting, etc. In addition, the repurchase programs of low-regulated firms on the Unlisted Public Company Market (UPCOM) and firms that are not listed on a major exchange should also be investigated since these programs are increasingly sophisticated and very easy to use as a tool to manipulate stock prices.

Author Contributions: All authors have made substantial contributions to the design and implementation of the research, to the analysis of the results, to the writing of the manuscript. All authors have read and agreed to the published version of the manuscript.

Funding: This research is supported by Ministry project \# B2018-NTH-17 and a result of the research group on 'Corporate Restructuring', Foreign Trade University (Vietnam).

Conflicts of Interest: The authors declare no conflict of interest.

\section{Appendix A}

Table A1. Definition of Variables.

\begin{tabular}{ll}
\hline DCA & Pre-stock repurchase discretionary current accruals \\
NDCA & Pre-stock repurchase non-discretionary current accruals \\
DA & Pre-stock repurchase discretionary total accruals \\
NDA & Pre-stock repurchase non-discretionary total accruals \\
INTEND & Ratio of the intended number of buyback shares to the total number of share outstanding \\
BTM & Natural log of 1 plus the ratio of the book value to the market value at the end of the \\
TA & previous fiscal year \\
LEV & Natural log of the total assets at the end of the previous fiscal year \\
OCF & Ratio of total debts to total equities at the end of the previous fiscal year \\
CASH & Ratio of operating cash flows to total assets at the end of the previous fiscal year \\
STATE & Ratio of cash plus short-term investment to total assets at the end of the previous fiscal year \\
CEOEDU & Percentage of state ownership \\
CEOTENURE & Equals 1 if the CEO has a master degree or above, 0 otherwise \\
CEOAGE & Nature log of the number of years as CEO \\
CEOGEN & Nature log of the age of the CEO in the announcement year \\
IND1 & Equals 1 if the CEO is male, 0 otherwise \\
IND2 & Equals 1 if the buyback firm is a real estate company, 0 otherwise \\
\hline
\end{tabular}

This table provides a summary of the variables that are included in the model to explain the completion of stock repurchase programs. 


\section{Appendix B}

Table A2. Corporate Governance and Investor Protection Index in 2017.

\begin{tabular}{cc}
\hline & Panel A \\
\hline & Corporate Governance Index in $\mathbf{2 0 1 7}$ \\
\hline This table provides information regarding the strength of the investor protection index of selected countries. \\
According to the World Bank, the corporate governance index is an average of five indices: the corporate \\
illegal corruption index, the corporate legal corruption index, the corporate ethics index, and the judicial/legal \\
effectiveness index. The index ranges from 0 to 100 and a higher value implies a higher corporate governance \\
& rating given by the country's enterprise sector \\
\hline Country & Corporate Governance Index (CGI) \\
Germany & 90.8 \\
United States & 89.8 \\
Australia & 88.4 \\
United Kingdom & 87.9 \\
Singapore & 80.9 \\
France & 73.7 \\
Malaysia & 66.7 \\
Thailand & 49.7 \\
Philippines & 48.9 \\
Indonesia & 44.7 \\
Vietnam & 38.1 \\
\hline
\end{tabular}

Panel B

\section{Investor Protection Index}

This table provides information regarding the strength of the Investor Protection Index of selected countries. According to the World Bank, the strength of the investor protection index is an average of three indices: the extent of disclosure index, the extent of director liability index, and the ease of shareholder suit index. The index ranges from 0 (little to no investor protection) to 10 (greater investor protection).

\begin{tabular}{cccccccc}
\hline Country & 2011 & 2012 & 2013 & 2014 & 2015 & 2016 & 2017 \\
USA & 8.3 & 8.3 & 8.3 & 8.3 & 8.3 & 6.6 & 6.5 \\
UK & 8.0 & 8.0 & 8.0 & 8.0 & 8.0 & 7.8 & 7.8 \\
France & 5.3 & 5.3 & 5.3 & 5.3 & 5.3 & 6.8 & 6.5 \\
Germany & 5.0 & 5.0 & 5.0 & 5.0 & 5.0 & 5.9 & 6.0 \\
Australia & 5.7 & 5.7 & 5.7 & 5.7 & 5.7 & 5.7 & 5.7 \\
Singapore & 9.3 & 9.3 & 9.3 & 9.3 & 9.3 & 8.0 & 8.3 \\
Malaysia & 8.7 & 8.7 & 8.7 & 8.7 & 8.7 & 7.4 & 7.8 \\
Thailand & 7.7 & 7.7 & 7.7 & 7.7 & 7.7 & 6.6 & 6.3 \\
Philippines & 4.0 & 4.0 & 4.0 & 4.3 & 4.3 & 4.2 & 3.8 \\
Indonesia & 6.0 & 6.0 & 6.0 & 6.0 & 6.0 & 6.1 & 5.3 \\
Vietnam & 2.7 & 2.7 & 3.0 & 3.0 & 3.3 & 4.7 & 4.5 \\
\hline
\end{tabular}

\section{References}

Andriosopoulos, Dimitris, Kostas Andriosopoulos, and Hafiz Hoque. 2013. Information disclosure, CEO overconfidence, and share buyback completion rates. Journal of Banking and Finance 37: 5486-99. [CrossRef]

Andriosopoulos, Dimitris, and Meziane Lasfer. 2015. The market valuation of share repurchases in Europe. Journal of Banking and Finance 55: 327-39. [CrossRef]

Babenko, Ilona, Yuri Tserlukevich, and Alexander Vedrashko. 2012. The credibility of open market share repurchase signaling. Journal of Financial and Quantitative Analysis 47: 1059-88. [CrossRef]

Barber, Brad, and Terrance Odean. 2001. Boys will be boys: Gender, overconfidence, and common stock investment. Quarterly Journal of Economics 116: 261-92. [CrossRef]

Bagwell, Laurie Simon. 1991a. Share repurchase and takver deterrence. RAND Journal of Economics 22: 72-88. [CrossRef] 
Bagwell, Laurie Simon. 1991b. Shareholder Heterogeneity: Evidence and Implications. The American Economic Review 81: 218-21.

Barclay, Michael, and Clifford Smith. 1988. Corporate Payout Policy: Cash Dividends vesus Open-Market Repurchases. Journal of Financial Economics 22: 61-82. [CrossRef]

Bens, Daniel, Venky Nagar, Douglas Skinner, and Franco Wong. 2003. Employee stock options, EPS dilution, and stock repurchase. Journal of Accounting and Economics 36: 51-90. [CrossRef]

Bhattacharya, Utpal, and Amy Dittmar. 2004. Costless versus costly signaling: Theory and evidence. In Working Paper. Bloomington: Indiana University.

Brav, Alon, John Graham, Campbell Harvey, and Roni Michaely. 2005. Payout Policy in the 21st Century. Journal of Financial Economics 77: 483-527. [CrossRef]

Brockman, Paul, Inder Khurana, and Xiumin Martin. 2008. Voluntary disclosures around share repurchases. Journal of Financial Economics 89: 175-91. [CrossRef]

Chan, Konan, David Ikenberry, Inmoo Lee, and Yanzhi Wang. 2010. Share repurchases as a potential tool to mislead investors. Journal of Corporate Finance 16: 137-58. [CrossRef]

Chan, Konan, David Ikenberry, and Inmoo Lee. 2004. Economic Sources of Gain in Stock Repurchase. Journal of Financial and Quantitative Analysis 39: 461-79. [CrossRef]

Chen, Chao. 2007. The Credibility of Stock Repurchase Signals. CSA Academic Perspective 3: 1-20.

Chen, Ni-Yun, and Chi-Chun Liu. 2020. Share repurchases and market signaling: Evidence from earnings management. International Review of Finance. forthcoming. [CrossRef]

Chevalier, Judith, and Glenn Ellison. 1999. Are some mutual fund managers better than others? Cross-sectional patterns in behavior and performance. Journal of Finance 54: 875-99. [CrossRef]

Cooper, Michael, Huseyin Gulen, and Michael Schill. 2008. Asset Growth and the Cross-Section of Stock Returns. The Journal of Finance LXIII: 1609-51.

Francis, Bill, Iftekhar Hasan, and Lingxiang Li. 2015. Evidence for the existence of downward real earnings management. In Research Discussion Papers 13/2015. Helsinki: Bank of Finland.

Fried, Jesse. 2005. Informed trading and false signaling with open market repurchase. California Law Review 93: 1323-86.

Gong, Guojin, Henock Louis, and Amy Sun. 2008. Earnings Management and Firm Performance Following Open-Market Repurchases. The Journal of Finance LXIII: 947-86.

Ginglinger, Edith, and Jean-Francois L'Her. 2006. Ownership Structure and Open Market Stock Repurchases in France. The European Journal of Finance 12: 77-94. [CrossRef]

Grullon, Gustavo, and Roni Michaely. 2002. Dividends, share repurchases and the substitution hypothesis. Journal of Finance 57: 1649-84. [CrossRef]

Guay, Wayne, and Jarrad Harford. 2000. The cash-flow performance and information content of diviđen increases versus repurchases. Journal of Financial Economics 57: 385-415. [CrossRef]

Hatakeda, Takashi, and Nobuyuki Isagawa. 2004. Stock price behavior surrounding stock repurchase announcements: Evidence from Japan. Pacific-Basin Finance Journal 12: 271-90. [CrossRef]

Ikenberry, David, Josef Lakonishok, and Theo Vermaelen. 1995. Market underreaction to open market share repurchases. Journal of Financial Economics 39: 181-208. [CrossRef]

Jagannathan, Murali, Clifford Stephen, and Michael Weisbach. 2000. Financial Flexibility and the Choice between Dividends and Stock Repurchases. Journal of Financial Economics 3: 355-84. [CrossRef]

Jones, Jj. 1991. Earnings management during import relief investigation. Journal of Accounting Research 29: 193-228. [CrossRef]

Kahle, Kathleen. 2002. When a buyback isn't a buyback: Open market repurchases and employee options. Journal of Financial Economics 63: 235-61. [CrossRef]

Lakonishok, Josef, and Theo Vermaelen. 1990. Anomalous Price Behavior Around Repurchase Tender Offers. The Journal of Finance XLV: 455-77.

Liu, Chao-Shin, and David Ziebart. 1997. Stock Returns and Open-Market Stock Repurchase Announcements. The Financial Review 32: 709-28. [CrossRef]

Manconi, Alberto, Urs Peyer, and Theo Vermaelen. 2019. Are buybacks good for long-term shareholder value? Evidence from buybacks around the world. Journal of Financial and Quantitative Analysis 54: 1899-935. [CrossRef] 
Moin, Abdul, Yilmaz Guney, and Izidin El Kalak. 2020. In search of stock repurchases determinants in listed Indonesian firms during regulatory changes. Journal of Economic Behavior and Organization 176: 145-65. [CrossRef]

Teoh, Siew Hong, Ivo Welch, and T. J. Wong. 1998. Earnings management and the underperformance of seasoned equity offerings. Journal of Financial Economics 50: 62-99.

Stephens, Clifford, and Michael Weisbach. 1998. Actual share reacquisitios in the open-market repurchase programs. Journal of Finance 53: 313-33. [CrossRef]

Vafeas, Nikos, Adamos Vlittis, Philippos Katranis, and Kanalis Ockree. 2003. Earnings Management Around Share Repurchase: A note. A Journal of Accounting, Finance and Business Studies 39: 262-72. [CrossRef]

Vermaelen, Theo. 1981. Common stock repurchases and market signaling. Journal of Financial Economics 9: 139-83. [CrossRef]

(C) 2020 by the authors. Licensee MDPI, Basel, Switzerland. This article is an open access article distributed under the terms and conditions of the Creative Commons Attribution (CC BY) license (http://creativecommons.org/licenses/by/4.0/). 